\title{
Assessment of Psychological Readiness Situation of Students Starting to Primary School
}

\author{
Medera Halmatov ${ }^{1}$ \\ ${ }^{1}$ Faculty of Education, Agri Ibrahim Cecen University, Agri, Turkey \\ Correspondence: Medera Halmatov, Faculty of Education, Agri Ibrahim Cecen University, Agri, Turkey. Tel: \\ 90-544-594-0404. E-mail: mederahalmatov@gmail.com
}

Received: December 8, 2017

Accepted: January 30, 2018

Online Published: April 27, 2018

doi:10.5539/ies.v11n5p85

URL: https://doi.org/10.5539/ies.v11n5p85

\begin{abstract}
There are important responsibilities expected from primary school students. The most important of these are the learning of reading, writing and arithmetic. There is a "psychological readiness" aspect besides reading, writing and arithmetic in order to be ready for the school. In this study, among the first-grade students, those who were academically ready were compared with those who were psychologically ready. In this research, screening model is used from quantitative research methods. Screening surveys allow the answers of questions such as "what, where, when, how often, at what level, how" (Wellington, 2006). The population of the research was composed of the children who started to the first class of primary schools in the provincial center of Ankara and the provincial center of Agri in the 2016-2017 academic year. The sample group of the study consisted of 327 students. 80 girls and 75 male students out of 322 students are chosen from the schools in the provincial center of Ankara, and 87 girls and 80 boys are chosen from the schools in provincial center of Ağrl. While the number of literate students at the basic level is 95 before the school starts, only 46 students are able to link shoe laces. While a total of 255 students knew all the main colors before the school started, only 31 students knew their home address. In addition, 90 students were found to have problems complied with the school rules. 39 students are shy in the classroom.
\end{abstract}

Keywords: school readiness, social skills, primary school, psychological readiness

\section{Introduction}

There are important responsibilities expected from primary school students. The most important of these is the learning of reading, writing and arithmetic. There is a "psychological readiness" aspect besides reading, writing and arithmetic in order to be ready for the school. Psychological readiness for primary school means that the child can keep up with school life. Unlike pre-school education institutions, it is expected from the children to obey the rules and the achievements are evaluated in the primary schools (Rybina, 2001; Gutkina, 2005).

In Turkey, the chronological age of the child is taken as a basis for the criterion for the children starting to primary education. Another criterion to consider is that the child is academically ready to the school (Sahin, Sak, \& Tuncer, 2013). Many studies have been done on the readiness of the children to the school. In most of these surveys, the criterion for starting school supports the academic skills and physical development of the child. Uyanık and Kandır (2010) emphasized the importance of early academic skills training in preschool period. In this research, they mentioned that early academic skills training promotes children's readiness to primary education and contributes to their success in advanced academic skills. The recommendations are given to the parents and educators working in this field about the features of literacy skills and math skills and the basic skill affecting these skills.

Erkan (2011) examined children's readiness to school according to the socioeconomic level of the family. The study found that the readiness level of the children in the upper socioeconomic group was higher than the children in the lower socioeconomic group. He picked on the fact that the reading and writing environment in the preschool period and the acquisition of verbal and mathematical skills are the crucial factors to prepare the child for the school. According to Tuncel (1992), children coming from an environment that offers a rich stimulating environment and experience in literacy, learn to read more easily. Erkan and Kırca (2010) examined the readiness of the first grade students having pre-school education to the school. In the survey, they mentioned that the school success is affected by the children's experience in reading and writing before the primary school. According to the results of the research, the readiness level of children taking pre-school education is higher than the children not taking pre-school education. Sarıçam and Halmatov (2012) examined the social rule perceptions of children with 
and without preschool education. As a result of the research, it is found that the children who take pre-school education have better social rule perceptions than children who do not take pre-school education.

It is seen in the researches on the students starting primary school that the students are more equipped in academic terms and they are inadequate in the social and self-care skills that will help the child to adapt to the school. Sahin, Sak, and Tuncer (2013) have examined the views of pre-school teachers and first-grade teachers on the preparation process for the primary school education. According to the results of the research, the pre-school teachers and first-grade teachers agree that all the development areas should be supported in the preparation process for the primary school education. The teachers who participated in the research also emphasized that children should not be taught to read and write before school. They also picked on the fact that the family is important in terms of readiness to the school and that they should cooperate with their families.

As a result of the above-mentioned researches, it can be concluded that in Turkey, it may be deducted that the acquisition of academic skills such as literacy and mathematical skills is at the forefront in the perception of "preparing children to the schools". When parents' attitudes towards raising children are considered, it is also a fact that the academic achievement of the children is more prevalent and the life skills are ignored. Many parents are only "focused" on their children's lessons, and they support their children more academically, not psychologically, when they prepare for the school.

Academic readiness to school includes the child's skills such as recognizing colors, letters and numbers, and counting by heart. Physiological readiness to the school includes the close and confidential relations of the child with the peers and teachers, verbal expression of the needs and feelings, participation to the activities (Borozinets, 1998; Volkova, 2001; Venger, 2005).

It is necessary for children who are starting the primary school to come to a certain level in terms of their physical, mental, social and emotional development to be able to keep pace with the innovations they face in the school and to be ready to fulfill the expectations in school successfully. A child who has reached the school maturity can easily fulfill the expectations and develop positive feelings and attitudes toward the school. A child who does not reach the school maturity may face some problems when they start the $1^{\text {st }}$ grade. A child who fails to fulfill the expectations in the school may have negative feelings towards the school and self, and the learning motivation may be impaired (Bolotina \& Komarova, 1998).

First-grade children who are "in race" with their peers need a variety of activities that will carry them to a "good place" on the social scene. Vygotsky has argued that they may experience an internal conflict between the feelings and impulses of the individual "interests" of 6-7 year old children and the attitudes to meet the social expectations. The new responsibilities they are facing, the changing expectations of their close circle, and the child's concerns about fulfilling these expectations reinforce the inner conflict. While trying to meet social expectations on the one hand, the child has to cope with the weakness of the control mechanism on his own impulses. The social expectations (parents, teachers) are an obstacle to meet the child's internal needs (Borodina, 2002; Kravtson, 2005).

According to Vygotsky, it is possible to collect pre-school children (6 years old) in two different groups in terms of school maturity.

1) The children who are psychologically ready to adapt the school.

The children in this group are ready to start the school, both physically and mentally. These children are able to control the impulses, and mature enough to obey rules and take responsibility.

2) The children who are not psychologically ready to adapt the school.

Children in this group are not psychologically ready to start school, although they are mature in physical terms. They are insufficient to obey the rules and take responsibility. They may experience adjustment problems in behaviors that require impulse control, such as doing homework, sitting in school desk, waiting for their turn, and being silent. Instead of taking such responsibilities, they may prefer to play games (Bojovich, 1968).

A crisis can occur when children, who are not psychologically ready for the school, take responsibility, as they do not gain the internal power to fulfill the expectations of the school. For example; to ask a child who does not "internally" have the responsibility of doing homework, and to ask a child who does not want to be separated from his/her mother to stay without her mother in the class is demanding something from the child that they "do not have". It is not possible to create a positive feeling about the school of a child who starts the school in this way. In particular, a child with a teacher and a parent that has a high expectation level may inevitably experience a conflict. Responsibilities that the child has to fulfill on the one hand, and the lack of potential to fulfill those responsibilities on the other, constitutes an internal conflict in the child. While the psychologically ready child is excited for 
starting the school, it is worrisome for the child who is not psychologically ready child to start school. "Vital" skills such as the ability to tie the shoe laces, to express their needs such as going to the toilet, to ask questions about things they do not understand during the lesson, and to memorize the phone number of their mother or father for a child starting the school is as important as reading and writing. It is inevitable that a child who can meet their needs independently will be more successful in adapting to a new orientation.

In this study, among the first-grade students, those who were academically ready were compared with those who were psychologically ready. It is assumed that the child is literate at the basic level, can count up to 100 , and knowing all the main colors is "Academically ready for the school". "Psychologically ready for school" is assumed that the child is able to obey the school rules, go to the school alone, tie the shoelaces, know the home address, and the telephone number of the parents. Within this framework, is the student who knows how to read or write or who can tie shoelaces among the first-grade students? Are the children who can count up to 100 or know their mother and father's phone number by heart? Is the student who knows all the colors or knows the address of the home by heart? To try to find answers to such questions.

\section{Method}

\subsection{Research Model}

In this research, screening model is used from quantitative research methods. Screening surveys allow the answers of questions such as "what, where, when, how often, at what level, how" (Wellington, 2006). In screening studies, information is usually gathered using the response options determined by researchers from a large group (Büyüköztürk et al., 2012).

\subsection{Study Group}

The population of the research was composed of the children who started to the first class of primary schools in the provincial center of Ankara and the provincial center of Ağr1 in the 2016-2017 academic year. A total of 322 students 167 (51.8\%) were female and 155 (48.2\%) were male. 80 girls and 75 male students out of 322 students are chosen from the schools in the provincial center of Ankara, and 87 girls and 80 boys are chosen from the schools in provincial center of Ağrı. The sample group was determined by simple random sampling method and according to the result of lots among the names of the schools in the centers of Ankara and Ağrn provinces. It was decided by lot again which class to include in the study among the schools that were chosen in the first lot and have more than one first-grade class in the school. All students from the class decided by the lot have been taken to the survey. In this way, 4 first-grade classes were selected from 4 different schools in Ankara province and 4 first-grade classes were selected from 4 different schools in Ağrı province center. The sample set is given in Table 1.

Table 1. Distribution of sample group by province and gender

\begin{tabular}{llll}
\hline & Ankara & A ğr & $\mathrm{N}$ \\
\hline Female & $80(51.6 \%)$ & $87(52 \%)$ & $167(51.8 \%)$ \\
Male & $75(49.4 \%)$ & $80(78 \%)$ & $155(48.2 \%)$ \\
Total & $155(48 \%)$ & $167(52 \%)$ & $(100 \%)$ \\
\hline
\end{tabular}

\subsection{Data Collection Tools}

An observation form created and configured by researchers was used as a data collection tool. In the configured observation, there is a coding system for the observer to collect and record information before the observation. In this method of observation, it is much easier to achieve reliability and validity in data collection (Büyüköztürk et al., 2012).

\subsection{Data Collection Method and Process}

The data for the study were collected from October 10 to 14 after three weeks from the beginning of the 2016 academic year (19 September). The researchers gave information about the purpose and data collection method of the research by interviewing class teachers of the classes determined by lot. Each class was noted in the observation form after each teacher assesses the students in their class according to the purpose of research. Teachers asked the questions on the observation form one by one to the students in the class. It was tested by the teacher whether the children can read and write, count up to 100, know all the colors and tie the shoelaces. The answers given by the student to questions such as home address, parents' phone number, etc. were then confirmed by communicating with the parents. Children, who have never participated in the activity, have difficulties in 
obeying the rules, and do not want to come to schools without their parent, are determined by the teacher.

\subsection{Data Analysis}

The information obtained through the teachers was coded and transferred to the data folder opened in SPSS package program. The data in the folder has been evaluated in accordance with the intended purposes. In the analysis of the data, statistical techniques such as percent (\%) distribution were used.

\section{Findings}

In this section, findings related to the questions that the answers were sought in the research. Findings were given as percentages of all the students who participated in the research and then as percentages between the provinces.

Table 2. Distribution of literate students at the basic level before the start of the course by provinces and gender

\begin{tabular}{lccc}
\hline & Ankara & Ağrı & $\mathrm{N}$ \\
\hline Female & 30 & 25 & 55 \\
Male & 25 & 15 & 40 \\
Total & 55 & 40 & 95 \\
\hline
\end{tabular}

In general, 95 (29\%) of the 322 students who participated in the survey were found to have read or write at a basic level before starting the school. When gender difference is considered, 55 of the 95 literate students are female students. $55(33 \%)$ female students of the 167 female students who participated in the research, and 40 male students (26\%) of the 155 male students were found to be literate at the basic level before starting the school. When the distribution of literate female students by provinces is examined, it is observed that $54 \%$ of the students are in Ankara and $46 \%$ of the students are in Ağrl. When the distribution of literate male students by provinces is examined, it is observed that $62 \%$ of the students are in Ankara and $38 \%$ of the students are in Ağrı. It is seen that the number of literate students in Ankara (55) is higher than the literate students in Ağrı (40).

Table 3. Distribution of the children knowing all the main colors before starting the school by provinces and genders

\begin{tabular}{lccc}
\hline & Ankara & Ağrı & $\mathrm{N}$ \\
\hline Female & 70 & 57 & 127 \\
Male & 72 & 56 & 128 \\
Total & 142 & 113 & 255 \\
\hline
\end{tabular}

In general, it is seen that $255(80 \%)$ of the 322 students who participated in the research know all the main colors before starting the school. By gender difference, 127 of the 255 students who know all the main colors are female and 128 are male students. It was determined that $127(76 \%)$ of the 167 female students who participated in the research, $128(82.5 \%)$ of the total 155 male students knew all the main colors before starting the school. When the table is examined, it is seen that 70 (55\%) female students in Ankara and $57(45 \%)$ female students in Ağr know all the main colors. When the distribution of male students by provinces is examined, it is seen that $72(56 \%)$ in Ankara and 56 (44\%) in Ağrı know all the main colors. It is seen that the number of students knowing all the main colors in Ankara (142) is higher than the students knowing all the main colors in Ağrı (128).

Table 4. Distribution of the children that can count up to 100 before starting the school by provinces and genders

\begin{tabular}{lccc}
\hline & Ankara & Ağrı & $\mathrm{N}$ \\
\hline Female & 76 & 68 & 144 \\
Male & 68 & 56 & 124 \\
Total & 144 & 124 & 268 \\
\hline
\end{tabular}

In general, it is seen that 268 ( $83 \%$ ) of the 322 students who participated in the research can count up to 100 before starting the school. By gender difference, 144 of the 268 students that can count up to 100 are female and 124 are male students. It was determined that 144 (86\%) of the 167 female students who participated in the research, 124 $(80 \%)$ of the total 155 male students can count up to 100 before starting the school. When the table is examined, it 
is seen that 76 (52.7\%) female students in Ankara and 68 (47.2\%) female students in Ağrl can count up to 100 . When the distribution of male students by provinces is examined, it is seen that $68(55 \%)$ in Ankara and $56(45 \%)$ in Ağr can count up to 100. It is seen that the number of students that can count up to 100 in Ankara (144) is higher than the students knowing all the main colors in Ağr1 (124).

Table 5. Distribution of the children that has difficulty in obeying the school rules by provinces and genders

\begin{tabular}{llll}
\hline & Ankara & Ağr1 & $\mathrm{N}$ \\
\hline Female & 23 & 12 & 35 \\
Male & 32 & 23 & 55 \\
Total & 55 & 35 & 90 \\
\hline
\end{tabular}

In general, it is seen that 90 (28\%) of the 322 students who participated in the research have difficulty in obeying the school rules. By gender difference, 35 of the 90 students that have difficulty in obeying the school rules are female and 55 are male students. It was determined that $35(21 \%)$ of the 167 female students who participated in the research, 55 (35\%) of the total 155 male students have difficulty in obeying the school rules (such as sitting in the school desk, being silent during the lesson, not playing any games during the lesson). 23 of 35 female students that have difficulty in obeying the school rules are in Ankara and 12 are in Ağrı. When the distribution of male students by provinces is examined, it is seen that 32 male students in Ankara and 23 male students in Ağrı students have difficulty in obeying the school rules. When the general difference between the provinces is examined, it is seen that the number of students that have difficulty in obeying the school rules in Ankara (55) is more than the students in Ağrı (35).

Table 6. The distribution of the students that do not want to come to school without the parents or relatives when starting the school

\begin{tabular}{lccc}
\hline & Ankara & Ağrı & N \\
\hline Female & 7 & 2 & 9 \\
Male & 18 & 11 & 29 \\
Total & 25 & 13 & 38 \\
\hline
\end{tabular}

Of the 322 students who participated in the research, $38(12 \%)$ did not want to come to the school without close relatives in the first days of their first year. When the gender difference of 38 students who do not want to go to the school alone is examined, 29 are male and 9 are female students. It is seen that $9(5 \%)$ of the 167 female students and 29 male students (19\%) of 155 male students do not want to go to the school alone. 7 of the 9 female students who do not want to go to the school alone are in Ankara and 2 in Ağrı. When the distribution of male students by provinces is examined, it is seen that 18 male students in Ankara and 11 male students in Ağr1 do not want to go to the school alone. When the general difference between the provinces is examined, it is seen that the number of students in Ankara (25) is higher than the number of students in Ağrı (13) that do not want to go to the school alone.

Table 7. Distribution of the students that behave shyly by provinces and genders

\begin{tabular}{lccc}
\hline & Ankara & Ağrı & $\mathrm{N}$ \\
\hline Female & 18 & 3 & 21 \\
Male & 14 & 4 & 18 \\
Total & 32 & 7 & 39 \\
\hline
\end{tabular}

Of the 322 students who participated in the research, $39(12 \%)$ were found to behave shyly. When the gender difference of the "shy" students is examined, 21 students are male and 18 students are female. It is seen that 21 (12\%) of 167 female students participated in the research, and 18 (12) of 155 male students behave shyly. 18 of the 21 female students who behave shyly are in Ankara, 3 in Ağrı. When the distribution of male students by provinces is examined, it is seen that 14 male students in Ankara and 4 male students in Ağrı behave shyly. When the general difference between the provinces is examined, it is seen that the number of students (32) behaving shyly in Ankara is higher than the students (7) in Ağrı. 
Table 8 . The distribution of the students that can tie the shoelaces by provinces and genders

\begin{tabular}{lccc}
\hline & Ankara & Ağrı & $\mathrm{N}$ \\
\hline Female & 11 & 18 & 29 \\
Male & 6 & 11 & 17 \\
Total & 17 & 29 & 46 \\
\hline
\end{tabular}

Of the 322 students who participated in the research, $46(15 \%)$ were found to be able to tie the shoelaces. When the gender difference of the students that can tie the shoelaces is examined, $29(17 \%)$ of 167 female students can tie the shoelaces and $17(11 \%)$ of 155 male students can tie the shoelaces. 11 of the 29 female students that can tie the shoelaces are in Ankara, 18 in Ağrı. When the distribution of male students by provinces is examined, it is seen that 6 male students in Ankara and 11 male students in Ağrı can tie the shoelaces. When the general difference between the provinces is examined, it is seen that the number of students that can tie the shoelaces in Ağrı (29) is higher than the students (17) in Ankara.

Table 9. Distribution of the students that know the telephone numbers of their mother by provinces and genders

\begin{tabular}{lccc}
\hline & Ankara & Ağrı & $\mathrm{N}$ \\
\hline Female & 6 & 7 & 13 \\
Male & 10 & 7 & 17 \\
Total & 16 & 14 & 30 \\
\hline
\end{tabular}

Of the 322 students who participated in the research, 30 (9\%) were found to know the telephone numbers of their mother by heart. When the gender difference of the students that know the telephone numbers of their mother is examined, 13 are female and 17 are male students. 13 (8\%) of 167 female students and $17(11 \%)$ of 155 male students know the telephone numbers of their mother. 6 of the 13 female students that know the telephone numbers of their mother are in Ankara, 7 in Ağrı. When the distribution of male students by provinces is examined, it is seen that 10 male students in Ankara and 7 male students in Ağrı know the telephone numbers of their mother. When the general difference between the provinces is examined, it is seen that the number of students that know the telephone numbers of their mother in Ankara (16) is higher than the students (14) in Ağr1.

Table 10. Distribution of the students that know the telephone numbers of their father by provinces and genders

\begin{tabular}{lccc}
\hline & Ankara & Ağrı & $\mathrm{N}$ \\
\hline Female & 9 & 9 & 18 \\
Male & 12 & 15 & 27 \\
Total & 21 & 24 & 45 \\
\hline
\end{tabular}

Of the 322 students who participated in the research, $45(14 \%)$ were found to know the telephone numbers of their father by heart. When the gender difference of the students that know the telephone numbers of their father is examined, 18 are female and 27 are male students. 18 (11\%) of 167 female students and 27 (17\%) of 155 male students know the telephone numbers of their father. 6 of the 9 female students that know the telephone numbers of their father are in Ankara, 9 in Ağrı. When the distribution of male students by provinces is examined, it is seen that 12 male students in Ankara and 15 male students in Ağrı know the telephone numbers of their father. When the general difference between the provinces is examined, it is seen that the number of students that know the telephone numbers of their father in Ağrı (24) is higher than the students (21) in Ankara.

Table 11. Distribution of the students that know the telephone numbers of their parents by provinces and genders

\begin{tabular}{lccc}
\hline & Ankara & Ağrı & $\mathrm{N}$ \\
\hline Female & 4 & 3 & 7 \\
Male & 7 & 6 & 13 \\
Total & 11 & 9 & 20 \\
\hline
\end{tabular}

Of the 322 students who participated in the research, $20(16 \%)$ were found to know the telephone numbers of their 
parents by heart. When the gender difference of the students that know the telephone numbers of their parents is examined, 7 are female and 13 are male students. 7 (4\%) of 167 female students and $13(8 \%)$ of 155 male students know the telephone numbers of their parents. 4 of the 7 female students that know the telephone numbers of parents father are in Ankara, 3 in Ağrı. When the distribution of male students by provinces is examined, it is seen that 7 male students in Ankara and 6 male students in Ağr know the telephone numbers of their parents. When the general difference between the provinces is examined, it is seen that the number of students that know the telephone numbers of their parents in Ankara (11) is higher than the students (9) in Ağrı.

Table 12. The distribution of students that know their home address by provinces and genders

\begin{tabular}{lccc}
\hline & Ankara & Ağrı & $\mathrm{N}$ \\
\hline Female & 3 & 9 & 12 \\
Male & 5 & 14 & 19 \\
Total & 8 & 23 & 31 \\
\hline
\end{tabular}

Of the 322 students who participated in the research, $31(10 \%)$ were found to know their home address. When the gender difference of the students that know their home address is examined, 12 are female and 19 are male students. 12 (7\%) of 167 female students and $19(12 \%)$ of 155 male students know their home address. 3 of the 12 female students that know their home address are in Ankara, 9 in Ağrı. When the distribution of male students by provinces is examined, it is seen that 5 male students in Ankara and 14 male students in Ağrı know their home address. When the general difference between the provinces is examined, it is seen that the number of students that know their home address in Ağrı (23) is higher than the students (8) in Ankara.

\section{Result, Discussion and Recommendations}

In this study, the academic readiness of the first-grade students of the primary schools in Ankara and Ağr provinces and the psychological readiness of the students were examined comparatively.

While the number of literate students at the basic level is 95 before starting the school, only 46 students are able to tie the shoelaces. A total of 268 students can count up to 100 . However, only 20 students know the phone number of both their parents. While a total of 255 students know all the main colors before starting the school, only 31 students know their home address. In addition, 90 students are found to have problems in obeying with the school rules. 39 students behave shyly in the classroom.

When the difference between provinces is examined, the students in Ankara were found to be more equipped academically. For example, 55 of the students in Ankara know how to read and write, while 40 students in Ağr know how to read and write. It is seen that the number of students in Ankara (142) that know all the main colors is more than the students in Ağrı (128). It has been determined that the number of students in Ankara (144) that can count up to 100 is more than the students in Ağrı (124).

The number of students who are psychologically ready to the school is found more in Ağr province. For example; 25 students in Ankara province did not want to go to the school without a close relative in the first days of school, while 13 students had the same problem in Ağrı. In Ankara province, 55 students had difficulty in obeying the school rules while 35 students had the same problem in Ağrı province. When we look at the shy children who cannot express their feelings and needs during the lesson, there are 7 students in Ankara and 7 students in Ağrı. While the number of students who know their home address is 8 in Ankara, 23 students in Ağr know their home addresses. While 30 students know their mother's phone number by heart, the number of students who know their father's phone number by heart is 45 . Students mostly know their father's phone numbers by heart.

As a result, among the 322 students who participated in the research, the number of students who are academically ready to the school is higher than the number of students who are psychologically ready to the school. While the students who are academically ready to the school are more in Ankara, the students who are psychologically ready to the school is more in Ağrı. It is possible to link the academic success of the children in Ankara to the factors such as the lower number of children in general, the educational opportunities of big cities, and the higher educational level of parents in Ankara. It is also possible to link psychological readiness of the children to the school in Ağrı to their living conditions. The fact that the number of children in the family is higher means that children are more sociable and audacious at a young age, the limited possibilities of a small city, and difficult climate conditions can lead the children to be more patient and more satisfied.

In the light of the abovementioned results, it is possible to say that the students who start the school have more 
academic support before starting the school. All the developmental process of children is supported in the Pre-school Education Institutions, where primary purpose is to prepare the children for the primary education. Looking at the result of this research, in the Preschool Education Institutions; it is possible to say that the academic skills such as reading and writing, recognizing numbers, knowing colors are more regarded. The results of this research can also give clues about parents' attitudes towards the subject. Achieving academic success in modern times is a fact that particular importance is given. In this sense, it is possible to say that the children participating in the research are supported more at home in the academic sense.

There are many studies supporting the results of this research. In a study conducted by Sahin, Sak, and Tuncer (2013), it was mentioned that students who started the school had problems such as the will to play games, disciplinary problems and not obeying the class rules. In the same study, it has been mentioned that teaching children how to read and write in preschool period leads to some negative results in first grade. Gülay (2011) mentioned in the research that the positive social behaviors also increased as the children's level of compliance with the school increased, and that the participation to the lesson and adaptation to the school of the shy children were low. Halmatov and Halmatov (2015) noted that parents support the children more in the academic sense. Erkan and Kurca (2010) have made suggestions for parents to do studies about reading and writing with their children at an early age.

Based on the results of the research, some suggestions can be made for educators, parents and other researchers. Although the academic background is important to start the school, skills such as the children's ability to meet their needs, express their feelings, and adapt to new environment are also necessary for children as well as academic skills. In pre-school periods, it is necessary to prepare the children for academic purposes as well as to prepare them psychologically to the school. It may be more necessary for a child to know his home address, to know his parents' phone number, to attach shoelaces than knowing the color in some living conditions. In this sense, it is possible to educate children to be self-sufficient in every way, to solve some problems alone, and to be academically successful at the same time. Particularly parents should think about what their children can and cannot do in environments where they are not present. Parents should ask the question to themselves "what would my child do if I were not with him?" In pre-school institutions, more time can be devoted to acquiring the skills for social and personal development of the child, as well as activities such as preparation for reading and writing, recognizing the colors and numbers, cutting and pasting, painting without overflowing. It should be considered what can be done in order to educate children who are academically successful as in Ankara and psychologically ready as in Ağrı.

Finally, it is possible to recommend the other researchers to conduct this research in a wider scale, to address the parents' attitudes towards the preparation for the school, and the ways to psychologically prepare the children to the school.

\section{References}

Bojovich, L. İ. (1968). Lichnost'i ee Formirovanie v Detskom Vozraste. M., 227.

Borodina, G. V. (2002). Eshe raz k Gotovnosti k Shkole. Nachal'naya Shkola: Pluys do i posle. M., 10, 19-25.

Borozinec, N., M. (1998). K Voprosu Psihologicheskoi Podgotovki k Shkole Detei s Trudnostyami v Obuchenii. Voprosy Psihologii. M., 2, 56-61.

Büyüköztürk, Ş., Kılıç-Çakmak, E., Akgün, Ö. E., Karadeniz, Ş., Demirel, F. (2012). Bilimsel araştırma yöntemleri. Geliştirilmiş 11. Baskı. Ankara: Pegem Akademi Yayınları. https://doi.org/10.14527/9789944919289

Erkan, S., \& Kırca, A, (2010). Okul öncesi eğitimin ilköğretim birinci sınıf öğrencilerinin okula hazır bulunuşluklarına etkilerinin incelenmesi. Hacettepe Üniversitesi Ĕ̈itim Fakültesi Dergisi, 38, 94-106.

Erkan, S. (2011). Farklı sosyoekonomik düzeydeki ilköğretim birinci sınıf öğrencilerinin okula hazır bulunuşluklarının incelenmesi. Hacettepe Üniversitesi Eğitim Fakültesi Dergisi, 40, 186-197.

Gülay, H. ( 2011). 5-6 yaş grubu çocuklarda okula uyum ve akran ilişkileri. Elektronik Sosyal Bilimler Dergisi, $10,1-10$.

Gutkina, N. İ. (1996). Psihologicheskaya Gotovnost' k Skkole. M., MGU, 64

Halmatov, S., \& Halmatov, M. ( 2015). Çocuklara temel can güvenliği eğitimi. Ankara: Nobel Akademik yayıncilik.

Kravzov, G. G. (2005). Shestiletni Rebenok. Psihologicheskaya Gotovnost’ k Shkole. M., MGU. 
Rybina, E. (2001). Gotov li Rebenok k Shkol'nomu Obucheniyu. Doshkol'noe Vospitanie, M., 8(1), 25-28.

Şahin, T. İ., Sak, R., \& Tuncer, N. (2013). Okul öncesi ve birinci sınıf öğretmenlerinin ilköğretime hazırlık sürecine iliş̧in görüşlerinin karşılaştırılması. Kuram ve Uygulamada Eğitim Dergisi, 13(3), 1691-1713. https://doi.org/10.12738/estp.2013.3.1665

Sarıçam, H., \& Halmatov, M. (2012). Okul Öncesi Eğitime Devam Eden ve Etmeyen Çocukların Ahlaki Ve Sosyal Kural Algılamalarının Karşılaştırılması. Uluslararası Hakemli Sosyal Bilimler E-Dergisi Akademik Bakış.

Tuncel, B. (1992). Okuma-Anlama Başarısı. İstanbul Üniversitesi, Sosyal Bilimler Enstitüsü (Yayımlanmamış Doktora Tezi) İstanbul.

Uyanık, Ö., \& Kandır, A. (2010). Okul öncesi dönemde erken akademik beceriler. Kuramsal Eğitim bilim Dergisi, 3(2), 118-134.

Venger, L. (2005). Kak Doshkol'nik Stanovit'sya Shkol'nikom. Doshkol'noe Vospitanie. M., 8, 66-74.

Volkova, E. T. (2001). Gotov li Rebenok k Shkole. Doshkol'noe Vospitanie. M., 12, 17-20.

Wellington, J. (2006). Educational research: contemporary issues and practical approaches. London: Continuum.

\section{Copyrights}

Copyright for this article is retained by the author(s), with first publication rights granted to the journal.

This is an open-access article distributed under the terms and conditions of the Creative Commons Attribution license (http://creativecommons.org/licenses/by/4.0/). 